LESSER, Jeffey.

\title{
A invenção da brasilidade: \\ Identidade nacional, etnicidade \\ e políticas de imigração
}

São Paulo: Editora Unesp, 2015. 206p.

\author{
ANDRÉ LUiz JoANILHO \\ Universidade Estadual de Londrina \\ Campus Universitário, Londrina, PR, 86.057-970, Brasil \\ alj@uel.br
}

Há obras que devem ser tratadas como tomadas de consciência de uma nacionalidade, mesmo que não tenham essa intenção. Autores que tratam daquilo que poderíamos chamar de "alma" nacional, acabaram indo um pouco além e dizendo mais do que intencionaram. É o caso do livro recém lançado de Jeffrey Lesser, $A$ invenção da brasilidade (São Paulo: UNESP, 2015). Pelo texto, pela pesquisa e pelas descrições históricas, o autor pretendia apresentar o Brasil para um público não brasileiro, mais especificamente, para um público norte-americano. No entanto, acaba dizendo mais sobre nós do que poderíamos esperar.

Mesmo que não se tenha colocado claramente, a obra é uma história comparada entre Brasil e Estados Unidos. Estão ali os mitos de origem. O Norte-americano é claro: a Terra Prometida, o Novo Israel, portanto, ali é o lugar de chegada e de construção do futuro. Já o nosso mito é uma não origem. Somos estrangeiros numa terra estrangeira. Na realidade, o nosso mito é um não mito: terra de passagem; terra de fronteira; confins

Recebido: 18 jan. 2016 | Aprovado: 22 fev. 2016

http://dx.doi.org/10.1590/0104-87752016000200011

Varia Historia, Belo Horizonte, vol. 32, n. 59, p. 579-582, mai/ago 2016 
do mundo. Como entender um lugar, um país cujo mito de origem é desmistificação da origem?

Jeffrey Lesser, conhecedor da nossa "alma", quer dizer, das nossas pequenas idiossincrasias, busca não ferir suscetibilidades nacionais, com algum tipo de crítica sobre o modo como construímos nosso país, ao contrário, apresenta uma narrativa clara e didática de como nós nos formamos. Bem ao inverso do mito americano: o país se forma de dentro para fora. Nós somos o de fora para um não dentro.

O país não é promessa de nada, a não ser de extração de riquezas (algo não dito, afinal sabemos disso, mas não queremos que fiquem dizendo isso por aí). Portanto, os recém-chegados não tinham (talvez não tenham ainda) nenhum compromisso com a terra de acolhimento, a não ser extrair o máximo possível e o mais rápido.

Tendo isso em vista (é bom lembrar, que não foi dito), Jeffrey Lesser nos apresenta um quadro constante de chegadas de povos que eram admitidos de acordo com circunstâncias e nenhum planejamento ou política específica de imigração. Vagas humanas imensas aportaram nestas terras tendo como único móvel, desejado ou não, encontrar o bem-estar econômico. Em momento algum, mesmo que inicialmente pudesse ser pensado, foram em direção ao seu "verdadeiro" lar, mesmo que imaginário. É claro que se pode objetar que mesmo os Estados Unidos não foram exatamente uma terra de acolhimento (e não foram mesmo), mas cultivaram o mito o suficiente para que se acreditasse nisso, diferença fundamental.

A intenção é anunciada, por Lesser, logo no começo: $A$ imigração é um tema que permite discutir o Brasil como "nação" (em termos de etnicidade e identidade nacional), paralelamente à postura mais tradicional, mas igualmente produtiva, de falar de "os Brasis" (p. 20). Sua diferença face a uma "tradição" historiográfica busca incluir o nosso país numa perspectiva não mais "excepcional", como é comumente tratada a nossa história, perante a América, mas como equivalente às formações das nacionalidades americanas, incluindo os Estados Unidos, isto é, a América é terra estrangeira (evidentemente que não para as populações autóctones, mas que os governos fizeram questão de também torná-las estrangeiras nas suas próprias terras). 
Assim, esta será a principal hipótese de Lesser, grupos de imigrantes se tornaram brasileiros ao incorporar a cultura majoritária, mas permaneciam como grupo distintos (p. 25). No entanto, o autor positivamente nos lembra que estas identidades não eram fixas, ao contrário. Por exemplo, mesmo "não brancos", isto é, não europeus, como árabes ou japoneses, se tornaram "brancos" no Brasil, pelo menos foi o modo que encontraram para negociar os seus lugares na sociedade brasileira. Assim, permanecer distintos significava, e significa, serem distintos no Brasil, mesmo que isso não tenha nenhuma correspondência real e efetiva com o lugar de origem. Chineses se tornam japoneses, árabes se tornam antepassados longínquos de indígenas, italianos do Tirol se tornam austríacos, descendentes de italianos se enobrecem, encontrando na internet possíveis brasões com nomes de famílias, assim por diante. Há um jogo constante das identidades conforme as circunstâncias.

Este padrão explicativo torna o livro mais interessante, pois nos apresenta um quadro geral, não exaustivo, da nossa formação, algo um pouco esquecido após a década de 1970. Histórias locais e regionais se tornaram muito mais comuns nos últimos anos, sendo abandonada qualquer perspectiva mais geral, como se a História do Brasil estivesse resolvida a partir da explicação econômica, por meio da linhagem estabelecida por Caio Prado Jr. Portanto, todas as outras histórias (políticas, sociais, culturais) só são possíveis graças, ou por causa desta linha mestra e única.

De certa maneira, sem expor isso claramente, é o que faz Jeffrey Lesser ao encontrar móveis gerais e específicos nesse processo. Se temas comuns como o branqueamento, a ideia de que o imigrante melhoraria o nosso, a busca de trabalhadores dóceis para a agricultura e de povoadores para as regiões fronteiriças apresentam a necessidade de compor uma população, a chegada de imigrantes nos mostra que na realidade se constituiu, ou ainda, acentua a diversidade do que seria a nossa "alma".

Dessa forma, após gerações, muitos brasileiros continuam sendo estrangeiros. Algo que afeta a nossa ideia de nacionalidade. Essa fluidez é uma marca da negociação da identidade nacional, para parafrasear o título do livro anterior de Jeffrey Lesser, Negociando a identidade nacional, 
UNESP, 2001. Grupos de imigrantes jogam o tempo todo com outros grupos e com aquilo que poderíamos chamar de ideias dominantes.

Mas, a grande questão é a que permanece, por que não se criou uma identidade tipicamente brasileira? A resposta não foi dada diretamente, mas através de toda a obra. Jeffrey Lesser aponta para a nossa especificidade: somos um povo tipicamente multicultural. Não no sentido que podemos ver nas grandes cidades europeias ou americanas, mas num sentido caracteristicamente sul-americano e brasileiro: incorporamos o que é estrangeiro na nossa identidade. Portanto, se na nossa origem está o herói sem nenhum caráter, com o nosso Brasil estrangeiro, acabamos nos tornando uma sociedade de indivíduos "multicaráter", um povo de mil faces. 